University of Nebraska - Lincoln

DigitalCommons@University of Nebraska - Lincoln

Agronomy \& Horticulture -- Faculty Publications

Agronomy and Horticulture Department

1965

Peroxidase and Polyphenoloxidase Activities and Free NinhydrinPositive Substances In Underground Buds of Ironweed and Leafy Spurge

\author{
W. G. Monson \\ United States Department of Agriculture \\ Francis A. Haskins \\ University of Nebraska-Lincoln, fhaskins@neb.rr.com
}

Follow this and additional works at: https://digitalcommons.unl.edu/agronomyfacpub

Part of the Plant Sciences Commons

\footnotetext{
Monson, W. G. and Haskins, Francis A., "Peroxidase and Polyphenoloxidase Activities and Free NinhydrinPositive Substances In Underground Buds of Ironweed and Leafy Spurge" (1965). Agronomy \& Horticulture -- Faculty Publications. 273.

https://digitalcommons.unl.edu/agronomyfacpub/273
}

This Article is brought to you for free and open access by the Agronomy and Horticulture Department at DigitalCommons@University of Nebraska - Lincoln. It has been accepted for inclusion in Agronomy \& Horticulture -Faculty Publications by an authorized administrator of DigitalCommons@University of Nebraska - Lincoln. 


\title{
Peroxidase and Polyphenoloxidase Activities and Free Ninhydrin-Positive Substances in Underground Buds of Ironweed and Leafy Spurge ${ }^{1}$
}

\author{
W. G. Monson and F. A. Haskins ${ }^{2}$
}

SYNOPSIS. Peroxidase activity in extracts of underground buds of ironweed and leafy spurge was at the lowest level during the period of dormancy in both species, and increased when dormancy was broken. Polyphenoloxidase activity of bud extracts was high for ironweed and very low for leafy spurge, and showed no relationship with dormancy in either species. Ninhydrinpositive substances generally and sulfur-containing amino acids in particular increased during the dormant period.

$\mathbf{B}^{\mathrm{C}}$ UD dormancy involves physiological phenomena, and studies of a biochemical nature are essential to gaining an insight into the processes concerned with causing or breaking dormancy. The literature on this subject is somewhat limited and is concerned primarily with woody species or with seeds. Work here (4) has shown that dormancy does occur in underground buds of ironweed (Vemonia baldwini Torr.) and leafy spurge (Euphorbia esula L.), and that in both species this dormancy is most pronounced in late summer and early fall.

Peroxidase and polyphenoloxidase are enzymes which occur widely in extracts of higher plants. Morris et al. (5) found that peroxidase may be involved in plant respiration. They also reported that plants lacking polyphenoloxidase are usually high in peroxidase and that the converse is also true. Mono- and polyphenoloxidases were shown to be involved in plant respiration. Arnon (1) and Dubuys et al. (2) showed that polyphenoloxidase seems to be associated with particulate portions of the cell, such as plastids and mitochondria.

The work reported here was initiated to study the seasonal fluctuation of peroxidase and polyphenoloxidase activity in extracts of buds from ironweed and leafy spurge. Protein nitrogen also was measured and ninhydrin-positive

\footnotetext{
${ }^{2}$ Published with the approval of the Director as Paper No. 1519, Journal Series, Nebraska Agricultural Experiment Station. Data were taken from a thesis submitted by the senior author in partial fulfilment of the requirements for the $\mathrm{Ph}$.D. degree. Mention of specific instruments and products is for identification only and does not imply any endorsement by the U. S. Department of Agriculture. Received for publication June 24, 1964.

${ }^{2}$ Formerly Assistant in Agronomy (now Research Agronomist, Crops Research Division, ARS, USDA Ithaca, N. Y.) and Professor of Agronomy, University of Nebraska, Lincoln, Nebraska.
}

substances were observed qualitatively at each sampling date. Although relationships between the measured attributes and dormancy have not been unequivocally established by these studies, results are presented here for their possible value to researchers who are interested in dormancy.

\section{EXPERIMENTAL PROCEDURE}

Extracts of bud material were prepared from plant samples which were brought to the laboratory at weekly intervals during the summer of 1957. The plant material was washed free of soil and the buds were excised and macerated in a chilled mortar with the aid of fine sand. Ten milliliters of glass-distilled water was added for each gram of bud material. The resulting slurry was centrifuged in a clinical centrifuge for 2 minutes and the supernatant was used for subsequent assays. Supernatants were used without dilution for chromatography, and were diluted 5 -fold with water for peroxidase assays. For polyphenoloxidase assays, ironweed supernatants were diluted 20 -fold and leafy spurge supernatants were used without dilution.

One-dimensional ascending chromatography on Whatman No. 1 filter paper was employed in the determination of ninhydrin-positive substances present in the bud extracts at each sampling date. 'Two solvent systems were used: 2 volumes n-propanol to I volume $1 \%$ ammonia, and 2 volumes n-propanol to I volume $1 \%$ acetic acid. Ninhydrin was used as the color reagent. Eighteen amino acids were chromatographed along with the unknowns at each date to aid in the identification of the substances present in the extracts.

Peroxidase and polyphenoloxiclase activities and protein $\mathrm{N}$ determinations were measured in a manner similar to that reported by Haskins (3). Preliminary studies were made to determine optimum levels of $\mathrm{pH}$, substrate, and enzyme preparation. The reaction mixture used for peroxidase activity consisted of $2.95 \mathrm{ml}$. of 0.01 $M$ sodium acetate $(\mathrm{pH} 6.5), 0.3 \mathrm{ml}$. of $0.18 \mathrm{M}$ guaiacol, $0.2 \mathrm{ml}$ of $0.029 \mathrm{M}$ hydrogen peroxide and $0.05 \mathrm{ml}$ of enzyme preparation. The reaction mixture for determination of polyphenoloxidase activity consisted of $2.9 \mathrm{ml}$. of $0.01 \mathrm{M}$ sodium acetate buffer ( $\mathrm{pH} 5.6$ ) $0.5 \mathrm{ml}$ of $0.5 M$ catechol and $0.1 \mathrm{ml}$. of the enzyme preparation. The cell of the Beckman model DU spectrophotometer served as the reaction vessel and optical density readings were made at 1-minute intervals fot a 5 -minute period. Measurements were made at $460 \mathrm{m \mu}$ for peroxidase activity and at $-110 \mathrm{m \mu}$ for polyphenoloxidase activity.

\section{RESULTS AND DISCUSSION}

Ninbydrin-positive iubslances. To simplify presentation, the assumption has been made that the ninhydrin-positive substances were free amino acids. The validity of this 
assumption is open to question because of the probable presence of small peptides and/or other amino acid derivatives in the tissue extracts. Nevertheless, the assumption is useful for comparative purposes.

Alanine appeared in extracts of leafy spurge buds in the months of June through October, however it did not appear in any extracts during May (Table 1). Arginine and aspartic acid appeared in all months May through September, except for June. Lysine was detected during the period of May through early August. The sulfur-containing amino acid, methionine, appeared only in August and September, while cystine occurred only in August. The appearance of the sulfur-containing amino acids and an increase in the number of amino acids detected in the extracts coincided with the occurrence of dormancy in leafy spurge. Tryptophan was detected in August. Glutamic acid and threonine appeared at irregular times during the sampling period. Other ninhydrin-positive spots were detected during the season. These were tentatively identified as phenylalanine, proline, and valine. Of the amino acids detected in acidhydrolyzed leafy spurge bud preparations, only serine was not detected without hydrolysis.

Chromatograms of ironweed bud extracts indicated that alanine was present during the months of July through September, but was lacking during May and June (Table 1). Spots corresponding to arginine were detected during June through September but not during May or October. Aspartic acid was present in extracts at nearly all sampling dates. Glutamic acid was found during May, June, July, and September. Tryptophan was present during August, September, and October and was detected infrequently in May. Methionine was detected during August and September. Several other ninhydrin-positive spots were recorded. These were tentatively identified as isoleucine, leucine, lysine, proline, serine, threonine, and tyrosine. Acid hydrolysates of the extracts of ironweed buds contained all of the amino acids indicated for unhydrolyzed extracts plus cystine. In agreement with the observations on leafy spurge, these observations indicate the presence of sulfur-containing amino acids and of an increased variety of amino acids in the buds of ironweed during the dormant period of late summer.

Protein nitrogen determinations. Protein nitrogen content of the ironweed bud extracts was relatively high and increased steadily throughout the season (Figure 1). The protein nitrogen increased from about 100 micrograms per $\mathrm{ml}$. of extract in early June to slightly over 700 micrograms per $\mathrm{ml}$. in late December.

Protein nitrogen content of leafy spurge bud extracts was extremely low at all sampling dates and was also quite variable (Figure 1). The amount of protein nitrogen in the crude extracts varied from less than 1 to slightly over 80 micrograms per $\mathrm{ml}$. of extract.

Enzyme studies. In assays of polyphenoloxidase activity in ironweed bud extracts, activity occurred almost entirely in the first minute after the enzyme preparation was added to the reaction mixture. The reaction pattern posed a problem in recording the activity of the enzyme over a period of time. It was determined that when more enzyme was added to the reaction mixture at the end of a 5-minute period, enzyme activity would again occur for about $1 \mathrm{~min}$ ute. (Figure 2). This pattern could be repeated for several 5-minute periods, thus the possibility that loss of activity was due to a lack of sufficient substrate was precluded.

Enzyme preparations from young corn shoots and ironweed buds were compared for activity on a series of sub-
Table 1. Ninhydrin-positive substances in leafy spurge and ironweed bud extracts. In the chromatographic systems used, the substances corresponded to the listed amino acids.

\begin{tabular}{|c|c|c|c|c|c|}
\hline May & June & July & August & September & October \\
\hline \multicolumn{6}{|c|}{ Leafy spurge } \\
\hline $\begin{array}{l}\text { Arginine } \\
\text { Aspartic acid } \\
\text { Glycine }\end{array}$ & $\begin{array}{l}\text { Alanine } \\
\text { Lysine } \\
\text { Glycine }\end{array}$ & $\begin{array}{l}\text { Alanine } \\
\text { Arginine } \\
\text { Aspartic acld }\end{array}$ & $\begin{array}{l}\text { Alanine } \\
\text { Arginine } \\
\text { Aspartlc acid }\end{array}$ & $\begin{array}{l}\text { Alanine } \\
\text { Arginine } \\
\text { Aspartic acid }\end{array}$ & $\begin{array}{l}\text { Alanine } \\
\text { Arginine } \\
\text { Glutamic } \\
\text { acid }\end{array}$ \\
\hline Lysine & Threonine & $\begin{array}{l}\text { Glutamic acid } \\
\text { Glycine } \\
\text { Lysine } \\
\text { Phenylalanine } \\
\text { Proline }\end{array}$ & $\begin{array}{l}\text { Cystine } \\
\text { Glycine } \\
\text { Histidine } \\
\text { Lysine } \\
\text { Methionine } \\
\text { Tryptophan } \\
\text { Valine }\end{array}$ & $\begin{array}{l}\text { Glutamic acid } \\
\text { Methionine } \\
\text { Proline }\end{array}$ & $\begin{array}{l}\text { Threo } \\
\text { nine }\end{array}$ \\
\hline \multicolumn{6}{|c|}{ Ironweed } \\
\hline $\begin{array}{l}\text { Aspartic acid } \\
\text { Glutamic acid } \\
\text { Lysine } \\
\text { Tryptophan } \\
\text { Tyrosine }\end{array}$ & $\begin{array}{l}\text { Arginine } \\
\text { Aspartic acid } \\
\text { Glutamic acid } \\
\text { lsoleucine } \\
\text { Serine }\end{array}$ & $\begin{array}{l}\text { Alanlne } \\
\text { Arginine } \\
\text { Aspartic acid } \\
\text { Glutamic acid } \\
\text { Proline }\end{array}$ & $\begin{array}{l}\text { Alanine } \\
\text { A rginine } \\
\text { Aspartic acid } \\
\text { Glycine } \\
\text { Histidine } \\
\text { Lysine } \\
\text { Methionine } \\
\text { Prollne } \\
\text { Serine } \\
\text { Threonine } \\
\text { Tryptophan } \\
\text { Tyrosine }\end{array}$ & $\begin{array}{l}\text { Alanine } \\
\text { A rginine } \\
\text { Aspartic acid } \\
\text { Glutamila cacid } \\
\text { Glyodne } \\
\text { Histldine } \\
\text { Isoleucine } \\
\text { Leucine } \\
\text { Methionine } \\
\text { Proline } \\
\text { Threonine } \\
\text { Tryptophan } \\
\text { Tyrosine }\end{array}$ & $\begin{array}{l}\text { Glycine } \\
\text { Lysine } \\
\text { Trypto- } \\
\text { phan }\end{array}$ \\
\hline
\end{tabular}

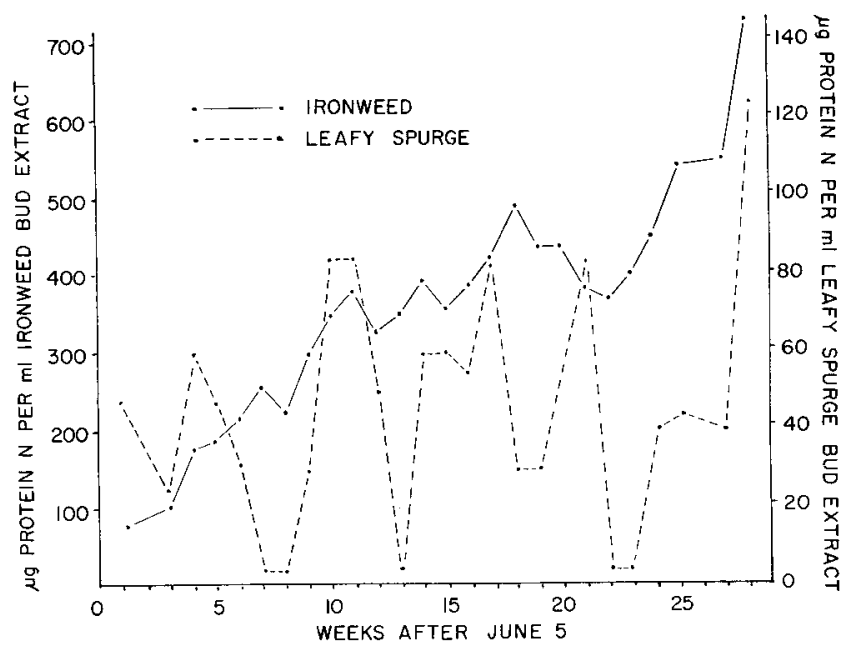

Figure 1. Protein nitrogen content of ironweed and leafy spurge bud extracts at weekly intervals during the growing season.

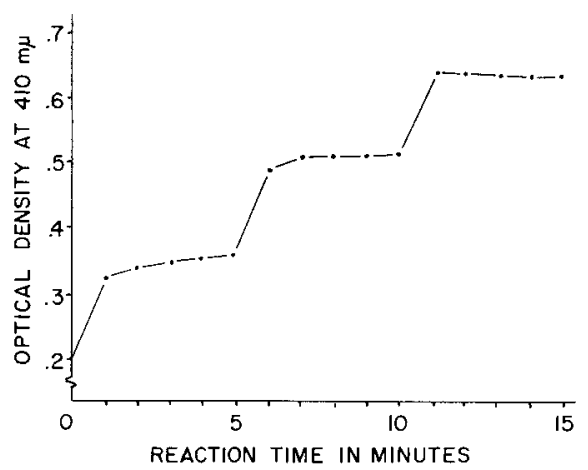

Figure 2. Polyphenoloxidase activity of ironweed bud extracts with repeated additions of enzyme preparation at 5 -minute intervals.

strate levels. At all but the lowest substrate levels, ironweed polyphenoloxidase activity occurred primarily during the first minute of reaction time. The corn extracts on the other hand, displayed faitly uniform polyphenoloxidase activity over a 5-minute period at all substrate levels tried.

The great rapidity of the color change in the ironweed polyphenoloxidase assays raised the question of whether 
or not the reaction was actually enzymatic in nature. Tests showed that boiling the enzyme preparation for 5 minutes reduced the color change essentially to zero as did the addition of $0.35 \mathrm{ml}$. of $0.01 \mathrm{M} \mathrm{KCN}$ to the reaction mixture. The addition of $0.035 \mathrm{ml}$. of $0.01 M \mathrm{KCN}$ caused the maximum color development to be reduced by approximately $50 \%$. In addition, after the first minute there was considerable fading of the color during a 5-minute period. These same tests when applied to extracts of young corn shoots gave similar results. Apparently, therefore, the color change observed in the ironweed polyphenoloxidase assays was truly enzyme dependent.

Polyphenoloxidase activity of ironweed bud extracts was high, as previously noted. Even though 20-fold dilutions of the original supernatants were used in the assays, the optical density of the reaction mixture frequently reached 0.8 to 1.0 after only 1 minute of reaction time. Specific activities of ironweed polyphenoloxidase are presented in Figure 3 as change in optical density per mg. protein $\mathrm{N}$ during the first minute of the reaction. As shown in the graph, values were quite variable, and no definite pattern of variation appeared although a tendency toward decreased activity was evident as the season progressed. This study did not reveal any relationship between the polyphenoloxidase activity of ironweed buds and bud dormancy in this species. The polyphenoloxidase activity of leafy spurge bud extracts was negligible at all sampling dates.

Peroxidase activity of ironweed bud extracts (Figure 4) was high during June and July and relatively low during August through early November. A marked increase was observed in late November and December. The lowest activities were recorded during the months of September and October.

When leafy spurge peroxidase activity was expressed on the basis of protein nitrogen, a pronounced peak was noted about August first, and activity then declined and remained low from mid-September through November (Figure 4). Thus, it appears that in both leafy spurge and ironweed, peroxidase activity is lowest during the period of greatest degree of bud dormancy (4). Although there is no reliable method of determining from these studies the significance of the association of low peroxidase activity with dormancy, peroxidase activity might well be utilized as an indicator of potential bud activity for leafy spurge and ironweed.

\section{SUMMARY}

Paper chromatography was used in the tentative identification of ninhydrin-positive substances in extracts of underground buds of leafy spurge sampled at weekly intervals throughout the growing season. The amino acid lysine occurred in samples collected from May to August. Alanine, arginine, aspartic acid, and glutamic acid were frequently found in the extracts. The sulfur-containing amino acids cystine and methionine were detected only during late summer at the time bud dormancy has been observed in this species. Ironweed bud extracts showed essentially the same pattern of amino acid content as the leafy spurge extracts. Tryptophan was also frequently present in the ironweed buds during August and September.

Leafy spurge bud extracts displayed an extreme peak in peroxidase activity about August first. Thereafter, activity declined rapidly, reaching a minimum during the months of September and October. Peroxidase activity of the ironweed extracts was at a maximum during the early part of the summer, then declined rather steadily. The lowest activities were recorded during the months of September and

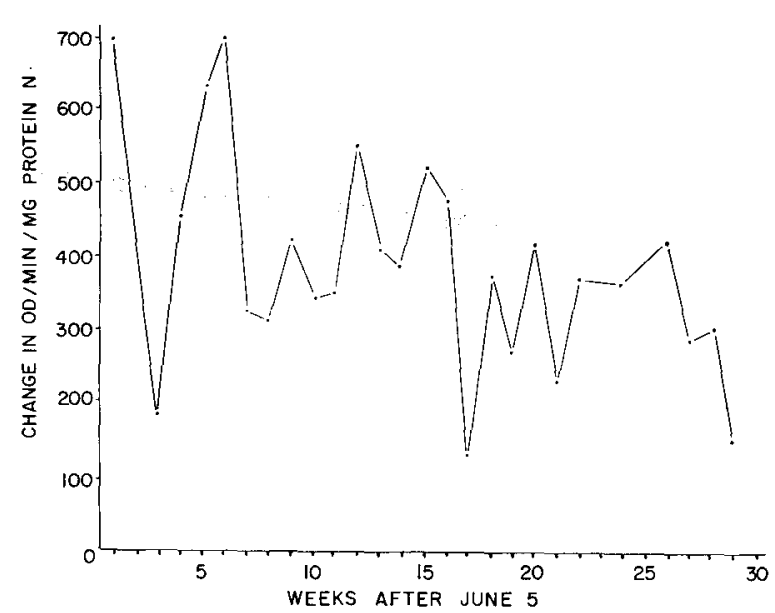

Figure 3. Polyphenoloxidase activity of ironweed bud extracts at weekly intervals during the growing season.

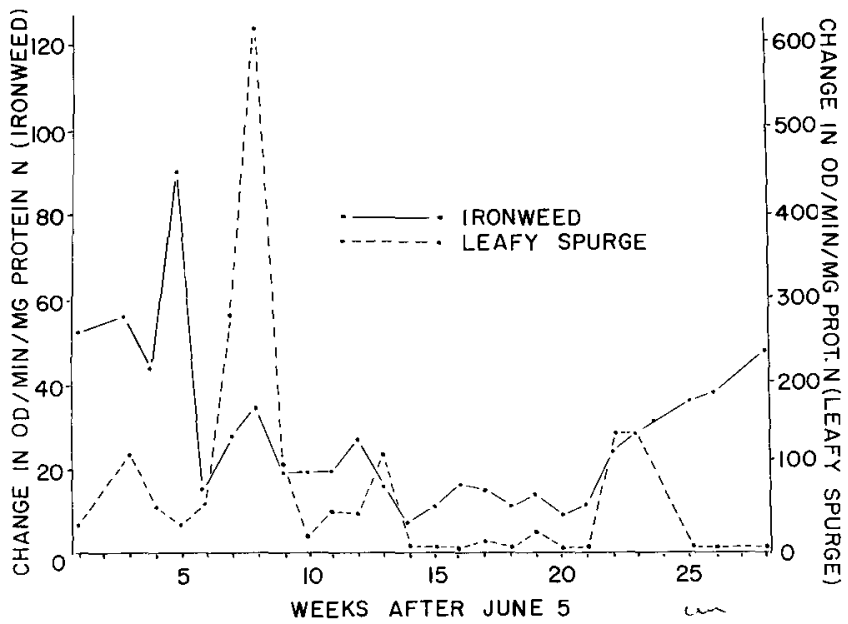

Figure 4. Peroxidase activity of ironweed and leafy spurge bud extracts at weekly intervals during the growing season.

October. Thus, it appears that in both of these species peroxidase activity is lowest during the period of greatest degree of bud dormancy. There is no reliable method of determining from these studies the significance of the association of low peroxidase activity with dormancy. However, peroxidase activity might well be utilized as an indicator of potential bud activity for leafy spurge and ironweed.

Polyphenoloxidase activity of leafy spurge bud extracts was negligible. Ironweed bud extracts exhibited high polyphenoloxidase activity at all sampling dates with no apparent relationship to dormancy. Ironweed polyphenoloxidase activity per unit of protein tended to decline during the season.

\section{LITERATURE CITED}

1. Arnon, D. I. Copper enzymes in isolated chloroplasts. Polyphenolase in Beta tulgaris. Plant Physiol. 24:1-15. 1949.

2. Duburs, H. G., Woods, M, W., and LAckney, M. D. Enzymatic activities of isolated normal and mutant mitochondria and plastids of higher plants. Science 111:572-574. 1950.

3. Haskins, F. A. Changes in the activities of several enzymes during gemination and seedling development in corn (Zea mays L.) Plant Physiol. 30:74-78. 1955.

4. Monson, W. G, and Davis, F. S. Some aspects of domancy in ironweed and leafy' spurge. "Weeds 12:238-239. 1964.

5. Morris, H. J. Weast, C. A., and Lineweaver, H. Seasonal variation in the enzyme content of eleven varieties of carrots. Bot. Gazette 107:362-372. 1946. 